Maja Škrobo
Osnovna škola "Rikard Katalinic Jeretov", Opatija

Sanja Šimleša

Jasmina Ivšac Pavliša

Sveuciliste u Zagrebu, Edukacijsko-rehabilitacijski

fakultet, Odsjek za logopediju

\section{Obilježja socijalne kognicije kod osoba s poremećajem iz spektra autizma, posebnim jezičnim teškoćama i intelektualnim teškoćama}

\author{
Features of Social Cognition in Individuals \\ with Autism Spectrum Disorder, Specific \\ Language Impairment and Intellectual \\ Disabilities
}

\begin{abstract}
SAŽETAK
Socijalna kognicija uključuje procese obrade socijalnih signala i spoznaju o ljudima kao o društvenim bićima (spoznaja o njihovim osjećajima, namjerama i motivaciji, znanjima i vjerovanjima). Općenito, ona se odnosi na sve kognitivne procese koji su aktivni u opažanju ponašanja i zaključivanju o mentalnim stanjima drugih ljudi. Odstupanja u razvoju socijalne kognicije mogu se prepoznati već u dojenačkoj dobi. U ovom radu prikazana su obilježja socijalne kognicije u tri različita tipa teškoća. Skupine djece s poremećajem iz spektra autizma (PSA-om), posebnim jezičnim teškoćama (PJT-om) i intelektualnim teškoćama pokazuju odstupanja u socijalnoj kogniciji, no njihova se obilježja socijalne kognicije razlikuju. U ranom razdoblju dok djeca još nemaju dijagnozu, moguće su teškoće u razlikovanju ovih poremećaja zbog sličnih obilježja. Poznavanjem razlika koje djeca pokazuju u razvoju socijalne kognicije, olakšana je i rana dijagnostika te diferencijalna dijagnostika između navedenih skupina. Budući da su obilježja socijalne kognicije povezana s usvajanjem jezika $i$ komunikacije, poznavanjem obilježja socijalne kognicije u ove tri dijagnostičke skupine logopedi će moći osmisliti i provoditi primjerene oblike podrške.
\end{abstract}

\begin{abstract}
Social cognition includes processing of social signals and understanding people as social beings (their feelings, intentions and motivation, knowledge and beliefs). In general, social cognition can be said to include all cognitive processes that involve other people. Deviations in the development of social cognition can already be recognized in infants. This paper describes the features of social cognition in three different types of childhood difficulty. Although groups with Autism Spectrum Disorder (ASD), specific language impairment (SLI) and intellectual disabilities all demonstrate deviations in social cognition, the features of social cognition are different in each group. At an early age, when most children still do not have a firm diagnosis, it can be hard to differentiate between these disorders because of their similar features. With an awareness of the differences children in these groups demonstrate in the development of social cognition, the early diagnostic procedure is easier and diagnostic procedures between groups can be differentiated. Because the features of social cognition are associated with language acquisition and communication, knowledge of the characteristics of social cognition in these three diagnostic groups will also help speech and language pathologists to implement appropriate support.
\end{abstract}

Ključne riječi: socijalna kognicija - teorija uma poremećaj iz spektra autizma posebne jezične teškoće intelektualne teškoće

Keywords: social cognition theory of mind Autism Spectrum Disorder specific language impairment intellectual disabilities 


\section{UVOD}

Ljudi su društvena bića. Većina toga što je čovječanstvo postiglo temelji se na radu u grupama, od prethistorijskog lova u grupama do današnjeg napretka tehnologije. Razmjenom znanja i iskustva s drugima, stvaraju se nove ideje i rješavaju problemi. Jedan od primjera važnosti društvenosti za ljude je i činjenica da je jedna od najstrožih kazni u zatvoru upravo socijalna izolacija.

Dijete je od rođenja u velikoj mjeri usmjereno socijalnim signalima te uživa $\mathrm{u}$ interakcijama s drugim ljudima (Ljubešić i Cepanec, 2012). Rane interakcije u kojima dijete sudjeluje u ovom razdoblju utječu na razvoj širokog raspona ljudskih sposobnosti. Razvojem djeteta dolazi do njegovog boljeg razumijevanja vršnjaka te odraslih osoba. Ono počinje shvaćati da se ljudi mogu razlikovati prema onome što žele, što znaju i u što vjeruju. Isto tako, dijete počinje shvaćati da se ciljevi drugih ljudi mogu razlikovati od njegovih vlastitih. Ono mora znati „pročitati“ što druge osobe žele, znaju i vjeruju iz njihovog ponašanja, onoga što rade i onoga što kažu te iz njihove facijalne ekspresije. Ovakvo razumijevanje drugih ljudi omogućuje socijalna kognicija.

Atipičnost u razvoju socijalne kognicije uzrokovat će teškoće razumijevanja ljudskih odnosa, nesposobnost shvaćanja mentalnih stanja drugih, namjera, želja i uvjerenja. Za komunikacijski razvoj iznimno je važno koliko i kako dijete obraća pažnju na socijalnu okolinu. Po obilježjima socijalne kognicije moguće je uočiti rana razvojna odstupanja i razlikovati razvojne profile (Ljubešić i Cepanec, 2012).

Budući da su prisutni nedostaci u socijalnoj komunikaciji i socijalnim interakcijama jedno od glavnih obilježja skupine djece s poremećajem iz spektra autizma (PSA-om), ujedno i kriterij Dijagnostičkog i statističkog priručnika duševnih poremećaja (DSM-V, 2013), mnoga su istraživanja usmjerena proučavanju socijalne kognicije kod ove skupine. Aspekt socijalne kognicije koji se najčešće ispituje zadacima pogrešnih vjerovanja je teorija uma. U novije vrijeme primijećene su teškoće u rješavanju ovih zadataka i kod skupina djece s posebnim jezičnim teškoćama (PJT-om) te s intelektualnim teškoćama, a time je i povećano zanimanje za istraživanje socijalne kognicije kod ovih skupina. Ovakvi nalazi dovode do pitanja univerzalnosti nedostataka teorije uma samo za pojedince sa PSA-om. Postavlja se pitanje kako neke osobe s PSA-om ipak uspješno rješavaju ove zadatke te utječu li možda uredne kognitivne sposobnosti na njihovu izvedbu. Isto tako, problem u ispitivanju teorije uma zadacima pogrešnih vjerovanja je utjecaj koji drugi aspekti razvoja mogu imati na rješavanje tih zadataka. Primjerice, što ako navedene skupine imaju problema u rješavanju zadataka pogrešnih vjerovanja zbog njihovih jezičnih teškoća ili teškoća u izvršnim funkcijama?

U ovom su radu opisana obilježja socijalne kognicije kod skupina djece sa PSA-om, PJT-om i intelektualnim teškoćama, s ciljem njihove usporedbe. Naime, različite kliničke skupine mogu pokazivati slične karakteristike u socijalnoj kogniciji, što dovodi do preklapanja simptoma i otežanog davanja dijagnoze. Poznavanjem razlika u socijalnoj kogniciji te utjecaja koji drugi aspekti razvoja imaju na socijalnu kogniciju, diferencijalna dijagnostika može biti olakšana, a time i stvaranje plana podrške u okviru rane intervencije kao i rada logopeda s djecom predškolske dobi. Obilježja socijalne kognicije su u vezi s komunikacijskim obrascem kao i usvajanjem jezika. Stoga je logopedima razumijevanje obilježja socijalne kognicije važno kako bi mogli primjereno poticati navedena obilježja kod djece sa sve tri navedene skupine teškoća. Poznavanje socijalne kognicije ključno je i za logopedski rad s djecom u razdoblju pred polazak u školu, kao i u školskom razdoblju, jer omogućava razumijevanje i primjereno poticanje djece koja pokazuju odstupanja u socijalnoj komunikaciji. Naime, odstupanja u uporabi jezika i socijalnom ponašanju smatraju se odrazom razumijevanja ljudi, njihovih očekivanja i znanja, čemu se u kliničkome radu još ne daje dovoljno pozornosti. $\mathrm{U}$ praktičnome radu logopedi procjenjuju i potiču komunikacijski i jezično-govorni razvoj kod sve tri skupine djece, zbog čega je također važno da na pravi način razumiju specifičnosti njihove socijalne kognicije.

U ovom radu opisana su obilježja socijalne kognicije obilježjima združene pažnje, imitacijskim sposobnostima, igrama pretvaranja $\mathrm{i}$ teorijom uma $\mathrm{u}$ navedenim trima skupinama. U praksi se ponekad socijalna kognicija izjednačava samo s teorijom uma, ali naglašavamo da ona obuhvaća i druge sposobnosti na koje će se autori osvrnuti u ovom radu.

Sposobnosti koje se odnose na socijalnu kogniciju te koje su ujedno preteče razvoja teorije uma mogu se razvojno pratiti još od uzrasta dojenčeta. Naime, već od rođenja djeca jako dobro prepoznaju ljudska lica (Johnson i Morton, 1991), a ubrzo nakon rođenja počinju prepoznavati poznate glasove, facijalnu ekspresiju i emocije (Woodhead, Barnes, Miell i Oates, 1995), kao i imitirati neke pokrete lica (Meltzoff, 2002). S oko 9 mjeseci kod djece se počinju razvijati novi oblici suradnje sa socijalnom okolinom jer djeca počinju ljude uvlačiti u svoje aktivnosti tako da počinju dijeliti predmete, slijediti i usmjeravati druge ljude. Te novonastale vještine nazivamo vještinama združene pažnje. Prema Tomasellou (1995), kada govorimo o vještinama združene pažnje mislimo na razumijevanje drugih ljudi kao intencijskih bića. Pod pojmom združivanja pažnje s drugima smatramo da osoba razumije, nadgleda i usmjerava namjere koje su u osnovi intencijskog ponašanja druge osobe. S oko 18 mjeseci djeca počinju razumijevati mentalno stanje pretvaranja. Igra pretvaranja uključuje situacije, predmete ili značajke predmeta koje nisu stvarne. U samom začetku, igra pretvaranja u velikoj mjeri je vođena od odraslih koji potiču djecu te im predlažu scenarije tijekom igre pretvaranja. U početku, igra pretvaranja je ovisna o prisutnim predmetima. Porastom dobi, djeca sama izmišljaju neke scenarije koji uključuju pretvaranje te su neovisnija o stvarnim predmetima.

U dobi između 3 i 5 godina djeca razvijaju teoriju uma. Premack i Woodruff (1978) postavili su osnovnu definiciju teorije uma, prema kojoj se radi o sposobnosti pripisivanja mentalnih stanja sebi i drugima. Nakon prvotne definicije, pojam teorije uma se upotrebljavao u različitim kontekstima te je gotovo nemoguće dati neku precizniju definiciju, pa se taj pojam najčešće upotrebljava kao širi pojam za opće znanje o umu i njegovoj ulozi, odnosno za dječje razumijevanje mentalnih stanja (Doherty, 2009). Osnovna mentalna stanja su želje i vjerovanja. Postoje tri razloga zbog kojih je razumijevanje želja i vjerovanja važno: za predviđanje ponašanja, objašnjavanje ponašanja i upravljanje ponašanjem. 


\section{Poremećaj iz spektra autizma}

Termin autistični poremećaj se u Dijagnostičkom i statističkom priručniku duševnih poremećaja (DSM-IV) svrstava u kategoriju pervazivnih razvojnih poremećaja uz Rettov poremećaj, dezintegrativni poremećaj u djetinjstvu, Aspergerov poremećaj te nespecificirani pervazivni razvojni poremećaj (American Psychiatric Association, 1994).

Izlaskom Dijagnostičkog i statističkog priručnika duševnih poremećaja (DSM-V, 2013), dolazi do promjena dijagnostičkog opisa i do uvođenja novog termina: poremećaj iz spektra autizma (PSA). PSA je definiran kao zajednički skup ponašanja te je stoga obilježen jednim nazivom i razlikuje se prema težini (Poremećaj iz spektra autizma prvog, drugog ili trećeg stupnja težine). Za dobivanje dijagnoze PSA-a, potrebno je zadovoljiti dva glavna kriterija: prisutnost nedostataka u socijalnoj komunikaciji i socijalnim interakcijama te prisustvo ograničenih, repetitivnih ponašanja, interesa i aktivnosti. Ako nisu prisutna ograničena, repetitivna ponašanja, interesi i aktivnosti, kod osobe se utvrđuje poremećaj socijalne komunikacije (American Psychiatric Association, 2013).

\section{Združena pa:̌nja}

Mnoga ponašanja koja uključuju vještine združene pažnje (primjerice: dijete dijeli pažnju združenim djelovanjem: pogleda predmet, zatim odraslog te ponovno predmet; slijeđeenje geste pokazivanja ili smjera pogleda druge osobe; usmjeravanje pažnje druge osobe na predmet svog interesa) razvijaju se postupno između 9 i 18 mjeseci kod djece urednog razvoja i postaju klinički značajan pokazatelj ako se ne jave u dobi od 18 mjeseci ili kasnije (García-Primo i sur., 2014). Istraživanja usmjerena obilježjima vještina združene pažnje (primjerice, praćenje pogledom i protodeklarativno pokazivanje) kod djece sa PSA-om pronalaze brojna odstupanja (Dawson i sur., 2004; Swanson i Siller, 2014).

Dawson i sur. (2004) proučavali su socijalno orijentiranje, združenu pažnju i reagiranje na nelagodu drugih te njihovu povezanost s jezičnim sposobnostima kod djece sa PSA-om (djeca dobi 3 do 4 godine), djece $\mathrm{s}$ razvojnim odstupanjima i djece urednog razvoja izjednačenima po mentalnoj dobi. Prilikom testiranja djetetovog odgovora na podražaj korišteni su zvukovi koje proizvodi čovjek i mehanički zvukovi. Rezultati su pokazali da djeca sa PSA-om postižu lošije rezultate na svim zadacima te manje odgovaraju na socijalne auditivne podražaje. U usporedbi s djecom s razvojnim odstupanjima, postignuće na zadacima združene pažnje pokazalo se najosjetljivijim diskriminatorom ovih dviju skupina.

\section{Imitacijske sposobnosti}

Djeca sa PSA-om pokazuju teškoće i u sposobnostima imitacije. Charman i sur. (1998) ispitivali su imitacijske sposobnosti kod 20-mjesečne djece sa PSA-om, nespecificiranim pervazivnim razvojnim poremećajem te djece s razvojnim odstupanjima. Ispitivač je modelirao 4 radnje s predmetima koji su nepoznati djetetu, od kojih je svaka ponovljena tri puta. Nakon toga, svi su predmeti stavljeni pred dijete i postavljeno je pitanje: „Što možeš učiniti s ovim predmetima?" Samo $50 \%$ djece sa PSA-om proizvelo je bar jednu imitacijsku radnju, dok je to činilo 85 $\%$ djece $\mathrm{s}$ nespecificiranim pervazivnim razvojnim poremećajem te $100 \%$ djece s razvojnim odstupanjima.

\section{Igra pretvaranja}

Djeca s PSA-om pokazuju ograničene kapacitete za kreativnu simboličku igru (igru pretvaranja). Charman i sur. (1998) promatrali su igru kod 20-mjesečne djece. Djetetu su nakon ulaza u prostoriju bile dostupne mnoge igračke (npr. set za čaj, pećnica, te pomagala poput slamke, kutije i slično). Niti kod jednog djeteta $s$ autizmom nije uočena igra pretvaranja, dok je uočena kod $25 \%$ djece s nespecificiranim pervazivnim razvojnim poremećajem i $50 \%$ djece $\mathrm{s}$ razvojnim odstupanjima.

Hobson, Lee i Hobson (2009) nastojali su procijeniti kvalitetu igre kod djece sa PSA-om. Rezultati su pokazali da ne postoje razlike između skupine djece sa PSA-om te skupine djece s teškoćama učenja i razvojnim odstupanjima u načinu igre. Naime, obje skupine su u igru uključivale zamišljene predmete, tako da jedna stvar predstavlja drugu, te pripisujući zamišljena obilježja predmetima. Ipak, skupina djece sa PSA-om pokazivala je manje kreativnosti i uživanja u igri. Međutim, riječ je o djeci školske dobi (9 i 10 godina), što podupire prijašnja istraživanja da s porastom kronološke dobi, djeca sa PSA-om pokazuju sposobnost zamjenjivanja jednog predmeta drugim u igri, bez sklonosti smišljanja novih scenarija pretvaranja.

\section{Teorija uma}

Većina istraživanja koja ispituju teoriju uma kod djece sa PSA-om usredotočena su na prijelazno razdoblje kad djeca počinju razumijevati pogrešna vjerovanja, oko četvrte godine života (Tager-Flusberg, 2007). Baron-Cohen, Leslie i Frith (1985) proveli su istraživanje u kojem je sudjelovalo 20 djece sa PSA-om urednog kognitivnog razvoja (IQ u prosjeku 82), 14 djece s Downovim sindromom te 27 djece urednog razvoja. Sve tri skupine ispitane su zadacima pogrešnih vjerovanja. Rezultati su pokazali da $85 \%$ djece urednog razvoja i $86 \%$ djece s Downovim sindromom točno rješava ove zadatke, dok čak 80\% djece sa PSA-om griješi na istima. Budući da su kognitivne sposobnosti skupine sa PSA-om bile više od kognitivnih sposobnosti skupine s Downovim sindromom, pronađeni nedostatak može se pripisati specifičnom kognitivnom nedostatku koji je neovisan o općem intelektualnom funkcioniranju (Baron-Cohen i sur., 1985). Ovi nalazi snažno podupiru tezu da skupina djece sa PSA-om ima značajnih teškoća u razvoju teorije uma.

Uzimajući u obzir različite kliničke slike PSA-a, Scheeren, Rosnay, Koot i Beeger (2013) ispitivali su složenije aspekte teorije uma (razumijevanje pogrešnih vjerovanja drugog reda, sarkazma, dvostrukih obmana) kod skupine s visokofunkcionirajućim autizmom (VFA) školske dobi i adolescenata. Utvrđeno je da kronološka dob sama po sebi nije presudna za uspjeh na ovim zadacima, već važnu ulogu ima i razina receptivnih verbalnih sposobnosti. Iako pojedinci s VFA rješavaju zadatke teorije uma, mogu imati teškoća pri suočavanju sa socijalnim zahtjevima u stvarnim 
socijalnim situacijama.

Univerzalnost nedostatne teorije uma za pojedince sa PSA-om dovedena je u pitanje istraživanjima, koja pokazuju da starija djeca s drugim poremećajima (npr. gluha djeca) također ne uspijevaju točno riješiti zadatke pogrešnih vjerovanja (Peterson, Wellman i Liu, 2005).

Postavlja se pitanje kako pojedina djeca sa PSA-om uspijevaju uspješno riješiti ove zadatke. Djeca urednog razvoja rješavaju ove zadatke intuitivnim socijalnim uviđanjem ili konceptualnim znanjima o mentalnim stanjima udruženim s općim kognitivnim vještinama koje podržavaju verbalnu obradu, pamćenje glavnih narativnih događaja te inhibiciju spontanih odgovora. Smatra se da djeca sa PSAom ovakvim zadacima pristupaju kao logičkim problemima, oslanjajući se primarno na jezik i druge nesocijalne kognitivne procese, umjesto socijalnim uviđanjem (TagerFlusberg, 2007).

Zaključno, djeca sa PSA-om imaju teškoća u pripisivanju mentalnih stanja sebi i/ili drugim ljudima, odnosno imaju nedostatke u teoriji uma (Tager-Flusberg, 2007). Imaju teškoće u razumijevanju socijalne okoline, koja je za njih nepredvidljiva i nerazumljiva te posljedično $\mathrm{i} u$ stvaranju socijalnih veza.

\section{Posebne jezične teškoće}

DSM-IV posebne jezične teškoće (PJT) svrstava u kategoriju komunikacijskih poremećaja, a razlikuje ekspresivni jezični poremećaj te miješani receptivnoekspresivni jezični poremećaj (American Psychiatric Association, 1994). Međunarodna klasifikacija bolesti i srodnih zdravstvenih problema (MKB 10, ICD; International Classification of Diseases) i DSM-IV navode kriterije koje je potrebno ispuniti za dijagnozu: jezično postignuće mjereno standardiziranim testom je ispod -2SD; jezične sposobnosti su bar 1SD niže od neverbalnih sposobnosti mjerenih na standardiziranom testu; nisu prisutna neurološka, senzorna ili fizička odstupanja. Razlikuju se receptivni jezični poremećaji (razumijevanje je ispod -2SD) te ekspresivni jezični poremećaji (proizvodnja je ispod -2SD, a razumijevanje prosječno) (World Health Organization, 1993). DSM-IV navodi dodatni kriterij da teškoće utječu na akademsko ili radno postignuće te na socijalnu komunikaciju (American Psychiatric Association, 1994). Izlaskom DSM-V uvodi se termin ,jezični poremećaj" (American Psychiatric Association, 2013).

Brojna istraživanja potvrdila su važnost združene pažnje, socijalnog zaključivanja i imitacijskih sposobnosti za usvajanje jezika. Međutim, kako se jezične teškoće ne prepoznaju u dojenačkoj dobi, kad se navedene sposobnosti razvijaju, manjkavi su podaci o njihovom razvoju kod djece sa PJT-om. Stoga su istraživanja koja imaju u središtu socijalnu kogniciju kod ove skupine više usmjerena predškolskom razdoblju.

\section{Zdrư̌ena pažnja}

Naprednim pretraživanjem ScienceDirect baze podataka, kojim su pretraživani članci koji u naslovu ili ključnim riječima imaju riječi ,joint attention“ i „specific language impairmet" - nije pronađen niti jedan rad.

\section{Imitacijske sposobnosti}

Naprednim pretraživanjem ScienceDirect baze podataka, kojim su pretraživani članci koji u naslovu ili ključnim riječima imaju riječi „,imitation“ i „specific language impairment" - nije pronađen niti jedan rad.

\section{Igra pretvaranja}

Stich (2010) je provela istraživanje u kojem je ispitivala teoriju uma i igru pretvaranja kod djece sa PJT-om. Roditelji skupine djece sa PJT-om ocijenili su socijalne interakcije svoje djece nižim brojem bodova nego što su to činili roditelji djece urednog jezičnog razvoja. Najveće razlike vidljive su $\mathrm{u}$ duljini vremena koju djeca provode $\mathrm{u}$ interakcijama s drugom djecom u vrtiću, gdje roditelji skupine djece sa PJT-om izvještavaju o manjoj količini vremena provedenog u takvim interakcijama s drugom djecom. Procjenom igre pretvaranja, ustanovljeno je da skupina djece sa PJT-om pokazuje manje učestale i jednostavnije oblike igre pretvaranja od njihove vršnjačke skupine.

\section{Teorija uma}

Ranija istraživanja teorije uma kod skupine djece sa PJTom nisu pronalazila nedostatke prilikom rješavanja zadataka pogrešnih vjerovanja (Andres-Roqueta, Adrian, Clemente i Katsos, 2013). Međutim, u ovim su istraživanjima djeca sa PJT-om imala višu kronološku dob te su bez teškoća rješavala zadatke kao kontrolna skupina prilikom istraživanja djece sa PSA-om. Miller (2004) je uspoređujući skupinu sa PJT-om sa skupinom urednog jezičnog razvoja izjednačenom po dobi, zaključila da ove dvije skupine postižu sličan uspjeh na zadacima pogrešnih vjerovanja kad je smanjena jezična složenost.

Farrar i sur. (2009) proveli su istraživanje, kojim su pokušali objasniti odnos jezičnih sposobnosti i teorije uma. Zadaci kojima je ispitivana teorija uma odnosili su se na zadatke pogrešnih vjerovanja o mjestu, sadržaju te zadatke razlikovanja pojavnosti od stvarnosti. Skupina djece sa PJTom podijeljena je u dvije podskupine: skupinu s umjerenim te skupinu s blagim jezičnim teškoćama. Skupina djece s umjerenim jezičnim teškoćama postizala je značajno lošije rezultate na zadacima teorije uma, s manje od $50 \%$ točnih odgovora. Iz navedenog možemo zaključiti da jezične sposobnosti utječu na rješavanje zadataka teorije uma.

$\mathrm{U}$ prilog tome govore $\mathrm{i}$ nalazi istraživanja AndresRoqueta i sur. (2013), koji su usporedili postignuća triju skupina na zadacima pogrešnih vjerovanja o mjestu i o sadržaju. Ispitivane su skupine djece sa PJT-om te dvije kontrolne skupine (jedna kontrolna skupina izjednačena je po dobi, a druga po jezičnom postignuću). Rezultati su pokazali da ne postoje značajne razlike između skupine djece sa PJT-om i kontrolne skupine izjednačene po jezičnom postignuću, ali su te razlike značajne kad je riječ o skupini djece sa PJT-om i kontrolnoj skupini izjednačenoj po kronološkoj dobi. Naime, skupina djece sa PJT-om postiže značajno lošije rezultate na zadacima pogrešnih vjerovanja. Ovaj nalaz govori u prilog tome da je postignuće na zadacima pogrešnih vjerovanja povezano s dobi te sa svim 
jezičnim varijablama: gramatičkim razumijevanjem te proizvodnjom, receptivnim i ekspresivnim rječnikom te semantičkim i pragmatičkim vještinama. $\mathrm{Na}$ osnovi navedenog može se zaključiti da su jezične sposobnosti prediktori izvedbe na zadacima pogrešnih vjerovanja.

\section{Intelektualne teškoće}

Termin intelektualne teškoće učestalije se upotrebljava posljednja dva desetljeća (American Psychiatric Association, 2013). Naime, u DSM-IV upotrebljava se termin mentalna retardacija pri opisu poremećaja koji je karakteriziran značajno ispodprosječnim intelektualnim funkcioniranjem kvocijent inteligencije (IQ) 70 ili niže, s početkom prije 18. godine života te $\mathrm{s}$ teškoćama $\mathrm{u}$ adaptivnim vještinama (American Psychiatric Association, 1994). AAIDD (The American Association on Intellectual and Developmental Disabilities, 2008; prema Owens, 2010) dodaje da su prisutna ograničenja vidljiva u konceptualnim, socijalnim i praktičnim vještinama.

$\mathrm{Na}$ osnovi različitog postignuća na testovima inteligencije, osobe $\mathrm{s}$ intelektualnim teškoćama mogu se podijeliti u četiri skupine: blage (IQ od 50-55 do 70), umjerene (IQ od 35-40 do 50-55), teže (IQ od 20-25 do 3540) i teške (IQ ispod 20-25) intelektualne teškoće (American Psychiatric Association, 1994). Izlaskom DSM-V uvodi se termin intelektualna onesposobljenost (intelektualni razvojni poremećaj), koji koristi i Svjetska zdravstvena organizacija (World Health Organization) te je učestalo u uporabi u medicinskim i edukacijskim sustavima (American Psychiatric Association, 2013). Ove se četiri skupine prema DSM-V dijele prema razini adaptivnog funkcioniranja, a ne mjerom kvocijenta inteligencije, iako su individualizirani testovi koji mjere kvocijent inteligencije sastavni dio procjene.

\section{Združena pažnja}

Zampini, Salvi i D'Odorico (2015) proučavali su združenu pažnju kod djece s Downovim sindromom starosti 18 mjeseci i 24 mjeseca te su istraživali odnos združene pažnje i razvoja rječnika. Rječnik je ponovno ispitan i šest mjeseci kasnije, kad su djeca imala 24 mjeseca i 30 mjeseci. Analizom podataka, uočeno je da su epizode združene pažnje bile jako česte u igri djece s Downovim sindromom. Nadalje, procjenom rječnika šest mjeseci kasnije, ustanovljeno je da je djetetova vještina združene pažnje značajan prediktor receptivnog rječnika.

\section{Imitacijske sposobnosti}

Naprednim pretraživanjem ScienceDirect baze podataka pri kojem su pretraživani članci koji u naslovu ili ključnim riječima imaju riječi ,imitation“ $i$,intellectual disabilities“ pronađeno je svega 5 radova. Međutim, kada se sagledaju uzorci sudionika u navedenim radovima pretežno se radilo o ispitivanju imitacijskih sposobnosti djece koja uz intelektualne teškoće imaju pridruženu i dijagnozu poremećaja iz spektra autizma. Na osnovi kliničkog iskustva autorica, možemo pretpostaviti da su imitacijske sposobnosti djece $s$ intelektualnim teškoćama uglavnom usklađene $s$ njihovom mentalnom dobi. Podatak o razini intelektualnih sposobnosti kod djece s intelektualnim teškoćama vrlo je važan za planiranje podrške za djecu rane dobi koja nisu dosegnula razinu verbalne komunikacije.

\section{Igra pretvaranja}

Brojna su istraživanja pokazala da mentalna dob djece s intelektualnim teškoćama predviđa složenost simboličke igre. Takvi nalazi podržavaju pretpostavku da djeca s intelektualnim teškoćama imaju zakasnjeli, a ne drukčiji razvoj, te samim time da će se njihova simbolička igra razvijati istim redoslijedom kao kod djece urednog razvoja (Nader-Grosbois i Vieillevoye, 2012).

\section{Teorija uma}

$\mathrm{U}$ istraživanjima teorije uma, djeca $\mathrm{s}$ intelektualnim teškoćama često su bila kontrolna skupina, dok su rijetko ispitivana posebno. Različita istraživanja promatrala su skupine različitih etiologija (Downov sindrom, nespecificirane intelektualne teškoće, PSA s intelektualnim teškoćama i sl.) koje mogu manifestirati različite razvojne „miljokaze“.

Nastojeći istražiti razvija li se socijalna kognicija djece s intelektualnim teškoćama u skladu s njihovom mentalnom dobi, Giaouri, Alevriadou i Tsakiridou (2010) ispitivali su teoriju uma kod skupine djece s Downovim sindromom, nespecificiranim intelektualnim teškoćama te kod skupine djece urednog razvoja. Skupine su izjednačene po mentalnoj dobi (oko 6;06), te su ispitane zadacima pogrešnih vjerovanja o mjestu i o sadržaju te zadacima razlikovanja pojavnosti od stvarnosti. Rezultati su pokazali da je skupina djece s Downovim sindromom postigla lošije rezultate od skupine s nespecificiranim intelektualnim teškoćama te skupine urednog razvoja. Podatak da se skupine djece s Downovim sindromom i nespecificiranim intelektualnim teškoćama razlikuju, može se interpretirati tako da nedostaci u teoriji uma mogu biti objašnjeni specifičnim kognitivnim fenotipom intelektualnih teškoća (Downov sindrom), a ne njihovim općim sposobnostima, što je potvrđeno i drugim istraživanjima (Giaouri i Alevriadou, 2010).

\section{Usporedba obilježja socijalne kognicije kod osoba s poremećajem iz spektra autizma, posebnim jezičnim teškoćama $\mathrm{i}$ intelektualnim teškoćama}

$\mathrm{Na}$ osnovi pregleda dosadašnjih istraživanja, može se zaključiti da sve tri navedene skupine pokazuju odstupanja u određenim aspektima socijalne kognicije. U ovom su poglavlju prikazana istraživanja usmjerena na usporedbu socijalne kognicije kod navedenih skupina.

Budući da je rani razvoj kod djece sa PSA-om karakteriziran kašnjenjem ili odsutnošću određenih ponašanja, moguće je razlikovati njihov razvoj od razvoja dojenčadi s intelektualnim teškoćama. Iako ove dvije kliničke skupine pokazuju atipičan razvoj, one se razlikuju u ranim odstupanjima koja pokazuju. Krajem prve godine života i u kasnijoj dobi očekuje se da će dojenčad s intelektualnim teškoćama pokazivati od stupanja sličnog intenziteta u 
mnogim domenama, uključujući jezične, komunikacijske, socijalne i motoričke vještine, dok se za dojenčad sa PSA-om očekuje da će pokazivati veća odstupanja u sposobnostima povezanim sa socijalnim vještinama, kao što su obraćanje pažnje na druge ljude te združena pažnja (Osterling, Dawson i Munson, 2002).

Osterling i sur. (2002) analizirali su kućne videozapise, na kojima su bila jednogodišnja djeca kod kojih su kasnije utvrđene intelektualne teškoće ili PSA. Autori su pokušali pronaći različita obilježja koje će im pomoći razlikovati skupine djece $\mathrm{s}$ intelektualnim teškoćama i PSA-om. Rezultati su pokazali da je moguće razlikovati ove dvije skupine već u dojenačkoj dobi. Skupina djece sa PSA-om rjeđe je monitorirala osobe u okolini, rjeđe se odazivala na ime te je češće pokazivala repetitivna motorička ponašanja nego skupina djece s intelektualnim teškoćama.

\section{Zdrǔ̌ena på̌nja}

Združena pažnja je važan čimbenik u komunikacijskom, jezičnom i kognitivnom razvoju djeteta, a istodobno je njezin nedostatak prepoznat kao jedan od prvih simptoma PSA-a, te su brojna istraživanja posvećena upravo ovom fenomenu.

Mundy, Sigman i Kasari (1990) usporedili su združenu pažnju kod skupine sa PSA-om te skupine s intelektualnim teškoćama. Rezultati su pokazali da je skupina djece sa PSAom postizala značajno lošije rezultate od kontrolnih skupina na zadacima združene pažnje. Ponovljenim testiranjem, nakon 13 mjeseci, rezultati pokazuju da je najbolji diskriminator skupine djece sa PSA-om i skupine djece s intelektualnim teškoćama - združena pažnja.

Djeca sa PSA-om pokazuju odstupanja u združenoj pažnji te je to jedan od važnih pokazatelja sumnje na PSA u ranoj dobi. Međutim, odstupanja koja postoje u vještinama združene pažnje ne mogu se kod ove skupine objasniti eventualnim kognitivnim odstupanjima - jer djeca sa PSAom mogu imati i uredan kognitivni razvoj kao i kašnjenje u kognitivnom razvoju, ali u oba slučaja značajno više odstupaju u vještinama združene pažnje. Međutim, kod djece $s$ intelektualnim teškoćama vještine združene pažnje djeteta usklađene su s mentalnom dobi djeteta, odnosno prate njegov kognitivni razvoj.

\section{Imitacijske sposobnosti}

Imitacijske sposobnosti najviše su ispitivane kod skupine djece sa PSA-om, dok su istraživanja imitacijskih sposobnosti kod djece sa PJT-om i intelektualnim teškoćama rijetka. Uglavnom se navedene dvije skupine navode kao kontrolna skupina djeci sa PSA-om.

Stone, Lemanek, Fishel, Fernandez i Altemeir (1990) istraživali su imitacijske sposobnosti te obrasce igre kod pet skupina predškolske djece: skupina djece sa PSA-om, intelektualnim teškoćama, gluhoćom, jezičnim teškoćama te skupina urednog razvoja. Kad je riječ o imitacijskim sposobnostima, rezultati pokazuju da je skupina djece sa PSA-om postizala značajno lošije rezultate od ostalih skupina sudionika.

\section{Igra pretvaranja}

Većina istraživanja usmjerila se na usporedbu obrazaca igre djece sa PSA-om te djece urednog razvoja i/ili djece $s$ intelektualnim teškoćama. Stone i sur. (1990) istraživali su imitacijske sposobnosti te obrasce igre kod pet skupina predškolske djece: skupina djece sa PSA-om, intelektualnim teškoćama, gluhoćom, jezičnim teškoćama te skupina urednog razvoja. Rezultati su pokazali da se skupina djece sa PSA-om igrala s manjim brojem igračaka nego gluha djeca, skupina s jezičnim teškoćama i skupina urednog razvoja. Nadalje, djeca sa PSA-om manje su vremena provodila u igri i manje su se vremena prikladno igrala s igračkama nego ostale grupe. S obzirom na razinu igre, djeca sa PSA-om manje su vremena provodila u funkcionalnoj igri, odnosno većina djece nije razumjela funkciju predmeta koji su im ponuđeni, te s obzirom na taj rezultat jasno je da nisu još bili niti na razini igre pretvaranja.

\section{Teorija uma}

Većina istraživanja teorije uma usmjerena je na PSA-a. $\mathrm{Na}$ osnovi nekih istraživanja, koja su uspoređivala djecu sa PSA-om i onu sa PJT-om, zaključuje se da djeca sa PJT-om postižu značajno bolje rezultate na zadacima pogrešnih vjerovanja (Gillott i Furniss, 2004).

Gillott i Furniss (2004) usporedivali su skupinu djece sa PJT-om (fonološko-sintaktički tip) sa skupinom djece sa PSA-om (visoko funkcionirajući) i skupinom djece urednog razvoja na zadacima teorije uma. Sva su djeca bila u dobi od 8 do 12 godina, a bila su uparena s obzirom na kronološku dob i spol. Ispitana su na zadacima koji su uključivali laži, pretvaranje, nesporazume, pojavnost/stvarnost, sarkazam itd., što podrazumijeva složenije razine teorije uma. Rezultati su pokazali da značajne razlike u broju odgovora koja se odnose na mentalna stanja (npr. „Zašto je x to rekao?“) postoje između skupine urednog razvoja i skupine djece sa PSA-om, te izmedu skupine urednog razvoja i skupine sa PJT-om, no ne i između skupina djece sa PSA-om i PJT-om. Moguće je da skupina djece sa PSA-om daje pogrešne odgovore zbog nedostataka u teoriji uma, dok skupina djece sa PJT-om griješi zbog generalnih teškoća u primjerenom izražavanju složenih odnosa. Loukusa, Mäkinen, KuusikkoGauffin, Ebeling i Moilanen (2014) u svom su istraživanju ispitivali skupine djece s PSA-om i PJT-om te ih usporedivali sa skupinom urednog razvoja. Cilj im je bio usporediti postignuća ovih skupina na podljestvicama NEPSY-II (teorija uma, verbalni i neverbalni kontekstualni zadaci). Rezultati su pokazali da su skupine djece sa PSA-om i PJTom postizale značajno lošije rezultate na verbalnim zadacima teorije uma nego skupina djece urednog razvoja, a na neverbalnim zadacima razlike nisu postojale. Povezanost između jezičnih testova i verbalnih zadataka teorije uma bila je viša kod skupine djece sa PJT-om nego kod skupine djece sa PSA-om.

Razlike u postignuću na zadacima pogrešnih vjerovanja između skupine djece sa PSA-om i intelektualnim teškoćama također su potvrđene u nekim istraživanjima (Ruffman, Garnham i Ridout, 2001). Naime, godinu prije nego što mogu uspješno riješiti zadatke pogrešnih vjerovanja, djeca urednog razvoja pogledat će na točnu lokaciju gdje bi Sally trebala tražiti svoj predmet (u košaru), iako će reći da će ga 
tražiti u kutiji. To usmjeravanje pogleda smatra se implicitnom mjerom zadataka pogrešnih vjerovanja, koja je temelj za kasniju eksplicitnu mjeru. Prilikom odgovaranja na pitanje „Gdje će Sally tražiti svoj predmet?“, skupina djece s intelektualnim teškoćama puno je češće usmjeravala pogled točno (implicitna mjera), nego što je to činila skupina djece sa PSA-om. Čak i kad bi dala točan odgovor, djeca sa PSAom puno su rjeđe usmjeravala pogled prema košari (Ruffman i sur., 2001).

\section{ZAKLJUČAK}

Važnost i učinkovitost rane intervencije prepoznata je već dulje vrijeme. Međutim, postoji raskorak između pojavljivanja simptoma, utvrđivanja teškoća (dijagnoze) te početka intervencije. Potrebno je dobro poznavati i razumjeti uredan razvoj kako bi bilo moguće prepoznati odstupanja pravodobno i pružiti odgovarajuću podršku. Odstupanja u razvoju socijalne kognicije mogu se prepoznati već u dojenačkoj dobi. Skupine djece sa PSA-om, PJT-om i intelektualnim teškoćama pokazuju odstupanja u socijalnoj kogniciji, no njihova se obilježja socijalne kognicije razlikuju. U ranom razdoblju, dok djeca još nemaju dijagnozu, ove je poremećaje teško razlikovati zbog sličnosti obilježja. Poznavanjem razlika koje djeca pokazuju u razvoju socijalne kognicije, olakšana je i rana dijagnostika te diferencijalna dijagnostika između navedenih skupina. Osim toga, poznavanjem aspekata socijalne kognicije koji odstupaju, a koji su uredni, stručnjacima će biti olakšano osmišljavanje programa intervencije te će znati na koje se aspekte trebaju usmjeriti kod koje skupine. Dakle, ranijim prepoznavanjem djece omogućen je što raniji početak intervencije, a time su povećani pozitivni rezultati.

Pregledom dosadašnjih istraživanja socijalne kognicije kod navedenih skupina, može se zaključiti da je prilikom procjene jednogodišnjaka potrebno posebnu pažnju posvetiti djetetovoj sposobnosti sudjelovanja i odgovaranja u socijalnoj okolini. Naime, djeca sa PSA-om značajno manje vremena provode u epizodama združene pažnje, nego što to čini skupina djece s intelektualnim teškoćama. Nadalje, razlike između ove dvije skupine prisutne su i u socijalnom zaključivanju i komunikacijskom razvoju, gdje je skupina djece sa PSA-om manje usredotočena na lica drugih te općenito pokazuje manji interes za ljude te se manje odaziva na ime. Kad je riječ o igri i imitacijskim sposobnostima, djeca sa PSA-om mogu se razlikovati od djece sa PJT-om i intelektualnim teškoćama po svom lošijem postignuću. Iako su porastom kronološke dobi sposobni zamjenjivati jedan predmet drugim u igri, pokazuju manje kreativnosti i nedostatak sklonosti smišljanja novih scenarija.

Kad je riječ o predškolskoj dobi i razvoju teorije uma, zaključuje se da skupina djece s PSA-om ne pokazuje potpuno odsustvo teorije uma, već kašnjenje u razvoju teorije uma. Naime, istraživanjima su potvrđene razvojne promjene. Pojedinci sa PSA-om ipak uspješno rješavaju zadatke pogrešnih vjerovanja, no ne rješavaju ih intuitivnim socijalnim uviđanjem, već im pristupaju kao logičkim problemima. Skupina djece sa PJT-om također pokazuje kašnjenje u razvoju teorije uma, ali zbog velikog utjecaja koji jezične sposobnosti imaju na rješavanje zadataka pogrešnih vjerovanja, može se zaključiti da ova skupina postiže lošije rezultate zbog generalnih teškoća u primjerenom izražavanju složenih odnosa, što potvrđuju i nalazi u kojima je skupina djece sa PJT-om postizala dobre rezultate kad su jezični zahtjevi bili sniženi. Kad je riječ o skupini djece s intelektualnim teškoćama, njihova mentalna dob predviđa uspješnost rješavanja zadataka pogrešnih vjerovanja. Dakle, ovi podaci govore u prilog tome da oni pokazuju zakasnjeli, a ne drukčiji razvoj teorije uma. Kad je riječ o pogrešnim vjerovanjima drugog reda, sve tri skupine pokazuju teškoće. Razlog tome može biti visoka jezična složenost takvih zadataka te teškoće izvršnih funkcija kod navedenih skupina, uključujući kratkoročno auditivno pamćenje, kontrolu inhibicije, metakognitivne sposobnosti te pažnju.

Stručnjaci moraju dobro poznavati obilježja urednih sociokognitivnih profila kako bi točno prepoznali dojenčad koja je rizična za PSA-a. Združena pažnja komponenta je vidljiva upravo u ranoj, predjezičnoj komunikaciji na koju se treba usredotočiti u intervenciji, posebno zbog njezine velike uloge u komunikacijskom, jezičnom i kognitivnom razvoju. Iako su nedostaci u socijalnoj kogniciji koje pokazuju skupine djece sa PJT-om i intelektualnim teškoćama odraz njihovih jezičnih i kognitivnih teškoća, bogatijim socijalnim interakcijama u svakodnevnim situacijama, češćim epizodama združene pažnje, pričanjem i čitanjem priča te igranjem uloga, dolazi do boljeg razvoja djetetovih jezičnih i kognitivnih sposobnosti te do boljeg shvaćanja drugih, odnosno do napretka i u socijalnoj kogniciji. Navedene smjernice su općenite te se smatraju poticajnima za sve opisane skupine djece. Međutim, kod djece sa PSA-om je u ranoj dobi nužno jačati jezične sposobnosti i približavati socijalne situacije primjenjujući vizualnu podršku i različite oblike potpomognute komunikacije, a u predškolskoj i školskoj dobi tumačiti socijalne situacije putem socijalnih priča. Djeca s intelektualnim teškoćama su također nerijetko korisnici potpomognute komunikacije pomoću koje se unapređuje njihova interakcija s drugima. Kod djece sa PJTom važno je jačati jezične sposobnosti i socijalne vještine posebno putem suradnje s drugom djecom, no ne nužno na eksplicitan način kao što je to opisano kod skupine sa PSAom $\mathrm{i}$ intelektualnim teškoćama.

\section{LITERATURA}

1) American Psychiatric Association (1994). Diagnostic and Statistical Manual of Mental Disorders (fourth edition). Washington, DC: American Psychiatric Association.

2) American Psychiatric Association. (2013). Diagnostic and statistical manual of mental disorders $(5$ th ed.). Arlington, VA: American Psychiatric Publishing.

3) Andres-Roqueta, C., Adrian, J.E., Clemente, R.A., Katsos, N. (2013). Which are the best predictors of theory of mind delay in children with specific language impairment? International Journal of Language \& Communication Disorders, 48 (6), 726-737.

4) Baron-Cohen, S., Leslie, A.M. i Frith, U. (1985). Does the autistic child have a theory of mind? Cognition, 21,37-46.

5) Bishop, D.V.M. (1997). Uncommon understanding: Development and Disorders of Language Comprehension in Children. Hove, United Kingdom: Psychology Press.

6) Charman, T., Swettenham, J., Baron-Cohen, S., Cox, A., Baird, G., Drew, A. (1998). An experimental investigation of social-cognitive abilities in infants with autism: clinical implications. Infant Mental Health Journal, 19 (2), 260-275. 
7) Dawson, G., Toth, K., Abbott, R., Osterling, J., Munson, J., Estes, A., Liaw, J. (2004). Early Social Attention Impairments in Autism: Social Orienting, Joint Attention, and Attention to Distress. Developmental Psychology, 40 (2), 271-283.

8) Doherty, J. M. (2009). Theory of Mind-How Children Understand Others' Thoughts and Feelings. Hove, UK: Psychology Press.

9) Farrar, M.J., Johnson, B., Tompkins, V., Easters, M., Zilisi-Medus, A., Benigno, J.P. (2009). Language and theory of mind in preschool children with specific language impairment. Journal of Communication Disorders, 42, 428-441.

10) García-Primo, P., Hellendoorn, A., Charman, T. i sur.(2014). Screening for autism spectrum disorders: state of the art in Europe. European Child \& Adolescent Psychiatry, 23, 1005-1021.

11) Giaouri, S. i Alevriadou, A. (2010). Second-order False Belief Attribution in Children with Non-specific Intellectual Disabilities and Down Syndrome: Social-cognitive Profile Research and Educational Planning Challenges. Buletinul Achizitiilor Publice, 62 (2), 102-108.

12) Giaouri, S., Alevriadou, A., Tsakiridou, E. (2010). Theory of mind abilities in children with Down syndrome and non-specific intellectual disabilities: An empirical study with some educational implications. Procedia Social and Behavioral Sciences, 2, 3883-3887.

13) Gillott, A. i Furniss, F. (2004). Theory of mind ability in children with specific language impairment. Child Language Teaching and Therapy, 20, 1-11.

14) Hobson, R.P., Lee, A., Hobson, J.A. (2009). Qualities of Symbolic Play Among Children with Autism: A SocialDevelopmental Perspective. Journal of Autism and Developmental Disorders, 39, 12-22.

15) Loukusa, S., Mäkinen, L., Kuusikko-Gauffin, S., Ebeling, H., Moilanen, I. (2014). Theory of mind and emotion recognition skills in children with specific language impairment, autism spectrum disorder and typical development: group differences and connection to knowledge of grammaticalmorphology, word-finding abilities and verbal working memory. International Journal of Language and Communication Disorders, 49 (4), 498-507.

16) Ljubešić, M. i Cepanec, M. (2012). Rana komunikacija: u čemu je tajna? Logopedija, 3 (1), 35-45.

17) McCabe, P.C. i Marshall, D.J. (2006). Measuring the Social Competence of Preschool Children With Specific Language Impairment: Correspondence Among Informant Ratings and Behavioral Observations. Topics in Early Childhood Special Education, 26 (4), 234-246.

18) Meltzoff, A. N. (2002). Elements of a developmental theory of imitation. U: A. N. Meltzoff i W. Prinz (Ur.), The imitative mind: Development, evolution, and brain bases (str. 19-41). Cambridge: Cambridge University Press.

19) Miller, C.A. (2004). False belief and sentence complement performance in children with specific language impairment. International Journal of Communication Disorders, 39 (2), 191-213.

20) Mundy, P., Sigman, M., Kasari, C. (1990). A Longitudinal Study of Joint Attention and Language Development in Autistic Children. Journal of Autism and Developmental Disorders, 20 (1), 115-128.

21) Nader-Grosbois, N., Vieillevoye, S. (2012). Variability of self-regulatory strategies in children with intellectual disability and typically developing children in pretend play situations. Journal of Intellectual Disability Research, 56 (2), 140156.

22) Osterling, J.A., Dawson, G., Munson, J.A. (2002). Early recognition of 1 -year-old infants with autism spectrum disorder versus mental retardation. Development and Psychopathology, 14, 239-251.

23) Owens, R.E. (2010). Language Disorders: A Functional Approach to Assessment and Intervention (Fifth Edition). New York: Pearson Education, Inc.

24) Peterson, C.C., Wellman, H.M., Liu, D. (2005). Steps in theory of mind development for children with autism and deafness. Child Development, 76, 502-517.

25) Premack, D. i Woodruff, G. (1978). Does the Chimpanzee Have a Theory of Mind.Behavioral and Brain Sciences, 1, 515-526.

26) Ruffman, T., Garnham, W., Rideout, P. (2001). Social understanding in autism: eye gaze as a measure of core insights. Journal of Child Psychology and Psychiatry, 42(8), 10831094.

27) Scheeren, A.M., Rosnay, M., Koot, H.M., Begeer, S. (2013). Rethinking theory of mind in high-functioning autism spectrum disorder. Journal of Child Psychology and Psychiatry, 54 (6), 628-635.

28) Stich, M. (2010). Theory of Mind and Pretend Play in Children with Specific Language Impairment. Doktorska disertacija. Department of Speech-Language Pathology of the University of Toronto.

29) Stone, W.L., Lemanek, K.L., Fishel, P.T., Fernandez, M.C., Altemeir, W.A. (1990). Play and Imitation Skills in the Diagnosis of Autism in Young Children. Pediatrics, 86 (2), 267-272.

30) Swanson, M.R. i Siller, M. (2013).Patterns of gaze behavior during an eye-tracking measure of joint attention in typically developing children and children with autism spectrum disorder.Research in Autism Spectrum Disorders, 7, 1087-1096.

31) Tager-Flusberg, H. (2007). Evaluating the Theory-ofMind Hypothesis of Autism. Current Directions in Psychological Science, 16 (6), 311-315.

32) Tomasello, M. (1995). Joint attention as social cognition. U: C. Moore i P. Dunham (Ur.), Joint attention : its origins and role in development (str. 85-101). Hilladale, New Jersey: Lawrence Erlbaum Associates.

33) World Health Organization (1993): The ICD-10 Classification for mental and behavioural disorders: Clinical descriptions and diagnostic guidelines. Geneva, Schwitzerland: World Health Organization.

34) Woodhead, M., Barnes, P., Miell, D. i Oates, J. (1995). Developmental Perspectives on Emotion. U: U. P. Barnes (Ur.), Personal, Social and Emotional Development of Children (str. 135-186). Oxford: The Open University/Blackwell.

35) Zampini, L., Salvi, A., D'Odorico, L. (2015). Joint attention behaviours and vocabulary development in children with Down syndrome. Journal of Intellectual Disability Research, 59(10), 891-901. 